\title{
Komunikasi Instruksional Pada Kelas Akting Online Sanggar Ananda
}

\author{
Ari Usman*, Devira Nafliyon, Wiliani \\ Program Magister Ilmu Komunikasi Unisba, Bandung Indonesia \\ "e-mail: ariusman026@gmail.com
}

\begin{abstract}
Basically, all the learning activities occurred in an educational institution between teacher and student can be classified as communication. In that kind of activity, teachers are intending to deliver teaching materials as direct messages to their students. Communication activity that is occurred within any learning environment is called instructional communication. Instructional communication can be found in both formal and non formal educational institutions. This study aims to obtain clear description about instructional communication that is occurred in the online acting class conducted by Sanggar Ananda (founded by Aditya Gumay) as a non formal educational institution. This study focuses on these three important aspects of instructional education: method, media, and barriers. This study uses a qualitative method with observation, deep interview, and literature study. The result of this study shows us that the instructional communication occurred in online acting class has been going very well. They do apply three type of methods simultaneously: lecture method, discussion method, and debriefing method. They also use video and whatsapp group as the media of the instructional communication.
\end{abstract}

Keywords: communication, instructional, learning

\begin{abstract}
ABSTRAK
Proses pembelajaran yang terjadi di lembaga-lembaga pendidikan sebenarnya merupakan sebuah proses komunikasi, di mana pengajar berupaya menyampaikan pesan berupa materi ajar kepada siswa atau peserta didik. Komunikasi yang terjadi dalam konteks pembelajaran disebut dengan komunikasi instruksional. Proses komunikasi instruksional sendiri dapat terjadi pada lembaga pendidikan formal maupun nonformal. Kajian ini bertujuan untuk mengetahui komunikasi instruksional yang berlangsung pada kelas akting online yang diselenggarakan oleh Sanggar Ananda pimpinan Aditya Gumay sebagai sebuah lembaga pendidikan nonformal. Kajian dilakukan dengan memberikan perhatian pada aspek metode, media, serta hambatan komunikasinya. Metode yang digunakan dalam penelitian ini adalah deskriptif kualitatif dengan teknik pengumpulan data secara triangulasi yang terdiri dari observasi, wawancara mendalam, serta studi dokumentasi. Hasil penelitian menunjukkan bahwa komunikasi instruksional pada kelas akting online yang diselenggarakan oleh Sanggar Ananda telah berlangsung dengan baik. Metode instruksional yang diterapkan merupakan gabungan dari metode ceramah, diskusi, dan tanya jawab. Adapun media instruksional yang digunakan adalah video materi akting serta grup whatsapp sebagai sarana interaksi antara siswa dengan pengajar.
\end{abstract}

Kata kunci : komunikasi, instruksional, pembelajaran

\section{Pendahuluan}

Komunikasi merambah dalam segala

aspek kehidupan manusia, salah satunya

adalah komunikasi instruksional yang dapat ditemui dalam praktik pembelajaran di lembaga-lembaga pendidikan.

Komunikasi instruksional memiliki E-ISSN: 2580-6955

makna sebagai bentuk komunikasi yang

Publisher : UMSU Press


berlangsung pada suatu bidang instruksional.

Perkataan instruksional diperoleh dari asal kata dalam bahasa Inggris yaitu instruction yang dapat diartikan sebagai pelajaran, pengajaran, atau instruksi (perintah). Namun, kata instruksional dalam konteks dunia pendidikan tidak dimaknai sebagai perintah, tetapi lebih pada pelajaran atau pengajaran, atau yang selanjutnya lebih dikenal sebagai pembelajaran (Zakiah \& Umar, 2006).

Komunikasi instruksional sendiri sebenarnya adalah sebuah sub dari komunikasi pendidikan. Komunikasi instruksional bertujuan menciptakan pemahaman pada komunikan yang menjadi targetnya, Pemahaman ini selanjutnya diharapkan akan membawa perubahan perilaku komunikan dari sisi kognitif, afektif, dan juga psikomotor (Yusup, 2010).

Penerapan komunikasi instruksional dapat dilihat pada proses pembelajaran guru dan siswa di sekolah, instruktur dengan peserta pelatihan, ataupun komunikasi yang terjadi di kantor antara atasan dengan bawahan (Barata, 2003).

UU Nomor 20 Tahun 2003 tentang Sistem Pendidikan Nasional menyebutkan bahwa pendidikan yang berlangsung di Indonesia dikelompokkan menjadi tiga jenis, yaitu pendidikan formal, pendidikan nonformal, dan pendidikan informal.

Dalam penerapannya, komunikasi instruksional digunakan bukan hanya pada lembaga pendidikan formal, namun juga E-ISSN: 2580-6955 dapat diterapkan pada kelas-kelas di lembaga pendidikan informal (Yusup, 2010).

Dalam sebuah lembaga pendidikan, tujuan utama yang ingin dicapai adalah bagaimana mengedukasi peserta pembelajaran agar dapat memahami materi ajar yang disampaikan.

Komunikasi instruksional memiliki fungsi asal edukatif, yaitu mengubah perilaku dari orang-orang yang menjadi sasarannya. Komunikasi dilakukan secara wajar, akrab penuh kehangatan, dan penuh keterbukaan didukung dengan faktor-faktor lainnya, baik sebagai sarana atau fasilitas lain yang dimaksudkan agar pihak sasaran mengalami efek berupa perubahan perilaku (Zakiah \& Umar, 2006).

Ada tiga faktor yang harus mendapatkan perhatian dalam sebuah kegiatan komunikasi instruksional, yaitu metode, media, dan hambatan (Absah, 2018).

Metode yang umum digunakan dalam komunikasi instruksional pada proses belajar mengajar adalah metode ceramah, diskusi, dan tanya jawab (Siregar \& Primasari, 2014).

Metode ceramah merupakan metode pengajaran di mana pengajar menyampaikan materi secara lisan kepada siswa. Dalam metode ini, kebanyakan siswa tersebut mengikutinya secara pasif.

Metode diskusi merupakan upaya memecahkan sebuah masalah yang tengah dihadapi oleh dua individu atau lebih. Masing-masing pihak mengajukan Publisher : UMSU Press 
argumentasi untuk memperkuat permasalahan atau opini yang sedang dibahas dalam diskusi tersebut. Metode diskusi bertujuan memberikan motivasi dan menstimulasi siswa untuk dapat berpikir kritis dan analitis.

Sedangkan dalam metode tanya jawab, pengajar memberikan pertanyaan untuk kemudian dijawab oleh siswa, atau sebaliknya siswa memberikan pertanyaanpertanyaan kepada gurunya.

Dalam implementasinya, komunikasi instruksional juga dapat menggunakan media. Media dalam kegiatan komunikasi instruksional ialah yang bentuk maupun fungsinya sudah dirancang sehingga dapat digunakan untuk memperlancar kegiatan proses belajar mengajar pada pihak sasaran, bahkan memperjelas gagasan yang disampaikan komunikator dalam kegiatannya. Ia juga berfungsi mengandung dan bahkan memperjelas ide-ide atau gagasan-gagasan yang disampaikan oleh komunikator dalam kegiatannya (Yusup, 2010).

Media pembelajaran dalam kegiatan komunikasi instruksional awalnya dikenal sebagai alat peraga, yang kemudian dikenal dengan istilah audio visual aids (alat bantu pandang/dengar). Selanjutnya disebut instructional materials (materi pembelajaran), dan kini istilah yang lazim digunakan dalam dunia pendidikan nasional adalah instructional media (media E-ISSN: 2580-6955 pembelajaran). Dalam perkembangannya, sekarang muncul istilah $e$-learning. Huruf " $e$ " merupakan singkatan dari elektronik. Artinya, media pembelajaran berupa alat elektronik, meliputi CD multimedia interaktif sebagai bahan ajar offline dan website sebagai bahan ajar online (Sumiharsono \& Hasanah, 2018).

Berdasarkan jenisnya, media yang dapat dijadikan pilihan saat ini antara lain media cetak, audio, visual, audiovisual, dan online (Nasrullah, 2016).

Dari beragam media komunikasi instruksional yang ada, pengajar dan atau lembaga harus menentukan dengan penuh pertimbangan, media apa yang paling tepat untuk kriteria sasarannya. Semua dilakukan agar pesan berupa materi ajar dapat tersampaikan kepada siswa sebagai komunikan secara efektif.

Setiap komunikator lazimnya mengharapkan agar proses komunikasi yang dilakukannya berlangsung efektif, pesan diterima dan dipahami oleh komunikan dengan efektif sebagaimana yang diinginkan komunikator. Namun, dalam sebuah proses komunikasi kerap ditemukan hambatanhambatan, tidak terkecuali dalam komunikasi instruksional.

Hambatan-hambatan yang ditemui dalam komunikasi instruksional merupakan penghalang yang dapat memengaruhi lancarnya sebuah kegiatan komunikasi instruksional. Hambatan-hambatan ini bisa Publisher : UMSU Press 
terjadi pada diri guru sebagai komunikator atau murid sebagai komunikan. Di samping itu, ketidaktepatan dalam pemilihan media serta kekeliruan ketika menyusun pesan merupakan hal-hal yang dapat menjadi kendala yang menjadi penghambat tercapainya tujuan pendidikan, maka hal-hal itu disebut dengan hambatan yang ada pada saluran komunikasi (Yusup, 2010).

Dari penjelasan mengenai hambatan di atas, dapat disimpulkan bahwa hambatan yang kerap ditemui dalam komunikasi instruksional adalah hambatan pada komunikator, hambatan pada media, dan hambatan pada diri komunikan.

Sanggar Ananda merupakan salah satu lembaga pendidikan nonformal yang menyelenggarakan pembelajaran mengenai public speaking, pembentukan kepercayaan diri, presenting, akting, modeling, menyanyi, dan dance. Sanggar ini berdiri sejak tanggal 25 Maret 1989 di Jakarta, memiliki motto: "Be Confident with Art" (Membangun Percaya Diri dengan Seni), meski tidak tampil di depan layar / tidak jadi bintang di panggung / film / sinetron, tapi jadilah bintang kehidupan.

Pada tahun 90-an, Sanggar Ananda dikenal berkat acara Lenong Bocah bergaya Betawi yang menjadi masterpiece dan berhasil meraih 6 piala Vidya pada Festival Sinetron Indonesia.

Acara Lenong Bocah ini kemudian melahirkan banyak artis muda berbakat yang E-ISSN: 2580-6955 hingga kini bisa dikenal masyarakat di antaranya Okky Lukman (pesinetron \& presenter), Melisa Grace (psikolog), Ruben Onsu (presenter, komedian, pemain film), Alm. Olga Syahputra (presenter, komedian, pemain film), dan lain-lain.

Sanggar Ananda berlokasi di empat titik Kota Jakarta (Manggarai, Cibubur, Bintaro, Rawamangun) serta satu cabang di Kota Bandung. Kegiatan pembelajaran dilakukan satu kali per minggunya. Para peserta yang mengikuti kegiatan pembelajaran dibagi ke dalam kelas-kelas berdasarkan kelompok usia.

Pelajaran seni yang diajarkan di Sanggar Ananda antara lain seni musik, seni tari, dan seni drama/akting. Pada saat awal bergabung, siswa akan mempelajari seluruh aspek dari pelajaran seni yang ada. Kemudian pada tahap selanjutnya pengajar akan memberikan penilaian dan juga saran mengenai bakat yang paling menonjol dari siswa tersebut.

Menyikapi perubahan era digital yang serba-online serta terkait masih merebak nya wabah pandemi Covid-19 yang mengakibatkan banyak aktivitas warga masyarakat terpaksa dibatasi, Sanggar Ananda juga menyelenggarakan kelas akting secara online. Media yang dipilih adalah video streaming dan grup WhatsApp.

Menurut Aditya Gumay selaku pendiri dan pemimpin Sanggar Ananda, masing-masing peserta memiliki tujuan yang 
beragam dalam mengikuti kelas akting online ini, baik mereka yang bertujuan untuk menjadi artis ataupun tujuan-tujuan lainnya. Dikatakan bahwa terdapat peserta kelas akting online dari kalangan guru sekolah. Mereka tertarik mengikuti kelas akting online karena membutuhkan materi pembelajaran akting untuk diajarkan pada saat pelajaran drama di sekolahnya masing-masing. Hal ini terutama dibutuhkan oleh guru Bahasa Indonesia dan Kesenian. Bahkan, di level TK sekalipun, guru memerlukan materi tentang akting karena terdapat bagian dari kurikulum yang mengharuskan adanya role play tentang bagaimana melakukan sandiwara dan akting yang harus dikuasai oleh para guru. Di DKI Jakarta sendiri, adanya guru yang mengikuti kelas akting online ini didukung oleh PGRI setempat. Lebih lanjut, Aditya Gumay mengatakan:

“Banyak guru yang belum dibekali pelajaran seni peran padahal di kurikulum pelajaran Bahasa Indonesia bahkan Sejarah ada, di mana anak-anak memainkan sandiwara pendek dari sebuah peristiwa sejarah yang dinilai oleh guru Sejarah. Bagaimana guru Sejarah, guru Bahasa Indonesia memberikan materi tentang akting ini kalau mereka tidak diberikan pengetahuan yang cukup. Video pembelajaran akting online ini akan menjadi jalan keluar bagi para guru baik Jabodetabek, Bandung, dan seluruh Indonesia untuk mendapatkan materi ini. “

\section{Metode Penelitian}

Penelitian ini menggunakan jenis penelitian deskriptif kualitatif, yaitu penelitian yang memanfaatkan wawancara terbuka untuk menelaah dan memahami sikap, pandangan, perasaan, dan perilaku individu atau sekelompok orang. Penelitian kualitatif biasanya memanfaatkan metode wawancara, pengamatan, dan pemanfaatan dokumen (Moleong dalam Zulfahmi, 2017).

Teknik pengumpulan data dalam penelitian ini adalah triangulasi, yang merupakan perpaduan dari observasi, wawancara mendalam, serta studi dokumentasi.

Purposive sampling menjadi teknik yang digunakan dalam penentuan informan. Peneliti menentukan bahwa informan kunci (key informant) dalam penelitian ini adalah Aditya Gumay, sebagai pendiri sekaligus mentor utama Sanggar Ananda yang telah terbukti menghasilkan siswa-siswi berprestasi yang mampu eksis di industri media hiburan Indonesia.

Adapun teknik analisis data yang digunakan mengacu pada apa yang dikemukakan oleh Sugiyono (2018) bahwa analisis data kualitatif adalah proses memilih, memilah, dan mengorganisasikan data yang terkumpul dari catatan lapangan, hasil observasi, wawancara mendalam, dan dokumentasi sehingga diperoleh pemahaman yang mendalam, bermakna, unik, dan berupa temuan baru yang bersifat deskriptif, kategorisasi, dan atau pola-pola hubungan 
antarkategori dari objek yang diteliti (Sugiyono, 2018).

\section{Hasil Penelitian dan Pembahasan}

Kelas Akting Online Sanggar Ananda mulai diselenggarakan pada bulan April 2020, berawal sebagai respons dari merebak nya wabah pandemi Covid-19 yang melanda dunia termasuk Indonesia. Selanjutnya Sanggar Ananda sendiri melalui pimpinannya Aditya Gumay menyatakan bahwa kelas akting online menjadi inspirasi bisnis baru, selain kelas akting offline yang rutin diselenggarakan. Bahkan, kelas online ini telah memiliki siswa dari luar negeri, seperti Taiwan, Hongkong, Malaysia, hingga Inggris. Maka walaupun ide ini muncul berawal dari menyikapi kondisi wabah Covid-19, kelas akting online ini rencananya akan terus diselenggarakan pada waktuwaktu mendatang.

Kelas akting online sendiri ditangani oleh sebuah tim khusus di Sanggar Ananda yang terbagi ke dalam dua tim, yaitu yang menangani pendaftaran siswa dan moderator pertanyaan-pertanyaan dari para siswa, serta tim promosi yang menangani hal-hal seputar promosi di ranah digital. Adapun lingkup materi yang diajarkan adalah mengenai akting, presenting, modeling, dan dance.

Pada saat mendaftar pertama kali, calon siswa akan diklasifikasikan ke dalam dua kelompok, yaitu kelas pemula, terdiri dari anak-anak dan orang dewasa yang belum pernah akting sebelumnya dan ingin mengetahui tentang akting. Kedua adalah kelas akting lanjutan, yang terdiri dari peserta yang telah mengikuti kelas pemula sebelumnya.

Durasi pelaksanaan kelas akting online berada dalam kisaran waktu 15-17 menit untuk kelas khusus akting. Materi akting dan presenter disampaikan langsung oleh Kak Aditya Gumay selaku mentor utama. Sedangkan untuk materi lain seperti modeling disampaikan oleh Kak Bobby dan Kak Intan, dan materi dance oleh Kak Yoga. Terkait metode komunikasi instruksional yang digunakan dalam kelas akting online Sanggar Ananda ini, proses diawali dengan metode ceramah yang dilanjutkan dengan metode diskusi dan tanya jawab. Metode ceramah dilakukan tidak hanya secara verbal, namun diiringi dengan peragaan langsung oleh pengajar dalam video.

Strategi komunikasi instruksional yang digunakan dalam kelas akting online ini lebih pada expository berupa pemaparan atau penjelasan yang dilakukan oleh para pengajar, dengan Kak Aditya Gumay sebagai pengajar utama. Pengajar mencontohkan langsung bagaimana cara berekspresi, apa itu blocking, serta bagaimana memberikan isi atau nyawa dalam sebuah dialog yang diucapkan. Dalam mempraktikkan materi ajar ini, dilibatkan juga anggota Sanggar Ananda yang diundang khusus agar siswa yang 
mengikuti kelas akting online dapat mencontoh gerakan-gerakan mereka.

Pada proses penyampaian materi ajar, pada kelas pemula digunakan penggabungan antara penyampaian teori akting dengan games yang berguna untuk membentuk suasana yang menyenangkan serta dapat melatih konsentrasi. Contohnya, permainan pegang hidung. Dua orang berhadapan dengan memegang hidung lalu ketika mereka menyebutkan satu kata misalnya pegang mata, tapi orang yang menyuruh bukannya memegang mata namun malah memegang dagunya atau rambut. Jadi, orang di depannya harus berkonsentrasi penuh, harus mengikuti kata-kata, bukan gerakan. Bila secara langsung dilakukan akan terganggu konsentrasinya karena mengikuti gerak bukan kata-katanya dan kadang kebisingan ramai anak-anak juga mengganggu konsentrasi. Oleh karena itu, pelajaran ini menjadi salah satu permainan sederhana yang bisa membantu anak-anak untuk berlatih berkonsentrasi penuh.

Sedangkan pada kelas akting lanjutan, proses pembelajaran dilakukan lebih serius dengan memperagakan dan mempelajari body language dalam berakting. Para siswa dapat memperhatikan contoh gerakan yang diperagakan oleh anggota Sanggar Ananda yang telah berpengalaman dengan dimentori oleh para pengajar.

Kegiatan komunikasi instruksional online dilakukan selama 14 hari, di mana E-ISSN: 2580-6955 secara kumulatif siswa akan mendapatkan tujuh video materi akting dari mentor utama Kak Aditya Gumay melalui video streaming yang dapat ditonton di google drive. Hal inilah yang menjadi perbedaan antara kelas akting offline dengan kelas akting online di mana dalam kelas akting offline kegiatan berlangsung secara tatap muka, siswa dapat bertemu langsung dengan pengajar dan terlibat dalam diskusi tanya jawab secara langsung, serta melakukan kegiatan bersamasama dengan siswa lainnya. Sedangkan dalam kelas akting online, pembelajaran dilakukan melalui video khusus yang dapat disimpan dan ditonton berkali-kali, siswa lebih fleksibel untuk mengakses video tersebut baik dari segi waktu ataupun lokasi, serta dalam kelas akting online ini siswa akan mendapatkan coaching langsung dari Kak Aditya Gumay selaku pimpinan Sanggar Ananda beserta pengajar-pengajar lainnya.

Video dipilih sebagai media dalam kegiatan komunikasi instruksional pada kelas akting online Sanggar Ananda karena sifatnya yang audiovisual. Mariotti (2009) melalui model the cone of learning menjelaskan bahwa kemampuan mengingat peserta didik diperoleh dari $10 \%$ membaca, $20 \%$ mendengar, $30 \%$ melihat, serta $50 \%$ audio dan visual (Anggarawati, 2019).

Setelah siswa mengakses video materi yang diberikan, maka mulai pukul 16.00 pada hari yang sama hingga pukul 10.00 keesokan harinya akan dibuka sesi diskusi dan 
pertanyaan di grup WhatsApp masingmasing. Siswa dapat menanyakan apa pun mengenai materi yang telah diajarkan, atau mengirimkan video latihan akting mereka. Secara umum kebanyakan siswa sudah dapat memahami isi video yang dikirimkan, tidak semua siswa mengajukan pertanyaan lanjutan. Setelah sesi pertanyaan ditutup pada pukul 10.00, selanjutnya pada pukul 16.00 Kak Aditya Gumay akan menjawab semua pertanyaan-pertanyaan dari peserta melalui pesan suara (voice note) termasuk mengomentari akting yang dilakukan peserta dalam video yang dikirimkan. Pada waktu ini juga diberikan tes untuk mengevaluasi pemahaman peserta atas materi yang telah dipelajari. Penilaian terhadap tingkat pemahaman siswa dalam kelas akting online ini disandarkan pada sejauh mana siswa tersebut mampu menjiwai setiap peran yang diberikan.

Ketika mengomentari video kiriman peserta, pengajar sekaligus memotivasi peserta dengan cara memberikan saran atas kelebihan dan kekurangan yang ditemukan dari akting peserta. Pengajar tidak akan segan untuk memberikan reward bagi peserta yang berhasil melakukan tes yang diberikan dengan baik dan benar agar mereka terpacu untuk lebih giat lagi berlatih dan belajar.

Lebih lanjut Aditya Gumay menyatakan bahwa tujuan yang diharapkan lewat penyelenggaraan kelas akting online ini adalah menjadikan siswa berani untuk tampil.
Setelah siswa memiliki keberanian untuk tampil, diharapkan akan dapat menumbuhkan kepercayaan pada dirinya. Melalui materi pembelajaran yang dikemas dalam bentuk video, siswa dapat lebih nyaman dalam mempelajarinya di rumah baik sendirian ataupun bersama anggota keluarga lainnya. Sampai saat ini kelas akting online telah berjalan terdiri dari tiga batch kelas pemula dan satu batch kelas lanjutan.

Selain video, media yang digunakan dalam komunikasi instruksional kelas akting online Sanggar Ananda adalah grup WhatsApp. Setiap peserta yang mendaftar akan bergabung di dalam grup WhatsApp dengan koordinatornya masing-masing. Tiap koordinator grup WhatsApp hanya dapat menjawab pertanyaan seputar hal-hal administratif seperti mengenai waktu, pembiayaan, atau aturan dalam kelas akting online. Selebihnya koordinator grup WhatsApp tidak berwenang menjawab pertanyaan seputar isi materi pembelajaran.

Karena grup WhatsApp ini ditujukan sebagai media komunikasi terkait kelas akting online, maka di grup WhatsApp ini juga diberlakukan aturan-aturan demi menjaga kondusivitas grup, di antaranya larangan mem-posting sesuatu yang tidak ada hubungannya dengan pelajaran akting, anggota grup tidak diperkenankan mengirimkan stiker, anekdot, hal-hal terkait SARA, bahkan berita-berita tentang virus 
corona. Hal ini dilakukan agar lalu lintas pembicaraan tidak mengalami kerancuan.

Terkait hambatan dalam kegiatan instruksional kelas akting online Sanggar Ananda, dari sisi komunikator tidak ditemukan hambatan yang berarti. Hal ini karena untuk pembelajaran kelas akting online ditangani langsung oleh Aditya Gumay selaku mentor utama yang telah berpengalaman selama puluhan tahun di dunia pembelajaran akting yang juga telah berhasil menelurkan siswa- siswi yang sukses di industri hiburan tanah air.

Dari sisi media yang digunakan, video pembelajaran dipersiapkan sebaik mungkin dengan mempertimbangkan hal-hal teknis yang lazim digunakan dalam pembuatan video berkualitas. Selain itu cara penyampaian dan isi materi disusun semaksimal mungkin dengan menyesuaikan pada komunikan yang menjadi sasarannya.

Hambatan barangkali ditemukan dari sisi siswa sebagai komunikan. Terdapat siswa yang pada saat memutar video pembelajaran beranggapan bahwa mereka sedang mengikuti siaran langsung sehingga kerap meminta agar materi dapat diulang. Padahal seharusnya mereka sendiri bisa mengulangulang video pada bagian yang diinginkan. Begitu juga, cara mengakses video yang mungkin bagi beberapa siswa merupakan hal yang baru.

\section{Penutup}

Komunikasi instruksional adalah bentuk komunikasi yang berlangsung dalam suatu bidang pembelajaran. Komunikasi ini dapat ditemukan pelaksanaannya dalam proses belajar mengajar baik di lembaga pendidikan formal maupun nonformal.

Agar sebuah kegiatan komunikasi instruksional dapat berjalan efektif, terdapat tiga hal yang harus mendapatkan perhatian, yaitu metode komunikasi instruksional yang diterapkan, media yang digunakan, serta hambatan-hambatan yang terjadi dalam proses komunikasi instruksional tersebut.

Sanggar Ananda merupakan sebuah lembaga pendidikan nonformal yang menyelenggarakan kelas akting online. Dalam proses instruksional nya, kelas belajar akting online Sanggar Ananda menggunakan metode ceramah, diskusi, dan tanya jawab secara simultan. Adapun media instruksional yang digunakan berupa 7 video materi akting yang dibagikan melalui video streaming yang dapat ditonton di google drive. Selain video, media yang juga digunakan adalah grup WhatsApp yang digunakan sebagai sarana komunikasi antara peserta dengan pengajar atau lembaga.

Secara keseluruhan kegiatan komunikasi instruksional pada kelas akting online Sanggar Ananda sudah berjalan dengan baik. Hambatan kecil ditemukan hanya terkait media yang digunakan di mana memerlukan adaptasi siswa sebagai 
komunikan terhadap proses pengaksesan materi ajar secara online.

Komunikasi instruksional merupakan bagian dari lingkaran besar komunikasi. Untuk menciptakan komunikasi instruksional yang efektif, komunikator harus merencanakan sebaik-baiknya kegiatan komunikasi yang dilaksanakan dengan meminimalisasi potensi hambatan yang dapat timbul.

\section{Daftar Pustaka}

Absah, S. (2018). Komunikasi Instruksional Instruktur pada Program Pelatihan Menjahit Pakaian di Balai Latihan Kerja (BLK) Pekanbaru. JOM FISIP Vol. 5, edisi II , 6.

Anggarawati, S. S. (2019). Komunikasi Instruksional sebagai Sarana Pengembangan Aktualisasi Diri Penyandang Tunanetra. Jurnal Manajemen Komunikasi, vol.3, no.2 , 146.

Barata, A. A. (2003). Dasar-Dasar Pelayanan Prima. Jakarta: Elex Media Komputindo.

Mariotti, A. P. (2009). Creating Your Teaching Plan: A Guide For Effective Teaching. Bloomington: AuthorHouse.
Nasrullah, R. (2016). Teori dan Riset Media Siber (Cybermedia). Jakarta: Prenadamedia Group.

Simkeu Kemdikbud. "UU No. 20 Tahun 2003 Tentang Sistem Pendidikan Nasional." http://simkeu.kemdikbud.go.id.

Siregar, N. A., \& Primasari, W. (2014). Strategi Komunikasi Instruksional Guru Bahasa Indonesia dengan Siswa di SMP Amal Mulia Klapanunggal Bogor. Jurnal Makna, vol.5, no.1 , 3940.

Sugiyono. (2018). Metode Penelitian Kualitatif. Bandung: Alfabeta.

Sumiharsono, R., \& Hasanah, H. (2018). Media Pembelajaran. Jember: Pustaka Abadi.

Yusup, P. M. (2010). Komunikasi Instruksional: Teori dan Praktik. Bandung: Bumi Aksara.

Zakiah, K., \& Umar, M. (2006). Komunikasi Instruksional dalam Proses Pembelajaran Mahasiswa. MediaTor Vo.7, No.1 , 128.

Zulfahmi. (2017). Pola Komunikasi dalam Upaya Pelestarian Reog Ponorogo pada Orang Jawa di Desa Percut Sei Tuan. Jurnal Interaksi , 228. 